doi.org/10.46291/ISPECIJSSHvol4iss4pp285-295

\title{
Mardin İli Geleneksel Halk Hekimliğinde Yanık Uygulamaları
}

\author{
Tekin Çifçi \\ Halit Demir \\ Dr., Hacı Hamdiye Özdemir Ortaokulu, Artuklu/Mardin, tekincifci02@gmail.com.
}

Orcid no: 0000-0002-1003-1711

Prof. Dr., Van Yüzüncü Y11 Üniversitesi, Fen Fakültesi, Kimya Bölümü, Biyokimya Anabilim

Dal1, halitdemi@gmail.com. Orcid no: 000-0002-2746-7941

Özet

Çevresel etkenlerin, gelenek, görenek ve tecrübeyle birleştirilmesiyle beraber yüzylllar içerisinde halk hekimliği ortaya çıkmıştır. Mardin'de, modern tıbbın gelişimine paralel olarak halk hekimliği yöntem ve uygulamaları da değişerek ve gelişerek varlığını sürdürmektedir. Bu çalışmada, Mardin geleneksel halk hekimliğinde önemli bir yeri olan yanık tedavisi uygulamaları, örnek bir yanık vakası üzerinden ele alınmıştır. Bu çalışmaya konu olan vaka, ilk günden itibaren izlemeye alınmış, yapılan uygulamalar düzenli aralıklarla görüntülenmiş ve kayıt altına alınmıştır. Kızgın yağın dökülmesi suretiyle hastanın sol eli yanmıştır. Mardin Devlet Hastanesi acil servisinde yapılan ilk muayenede 2. derece yanık teşhisi konulmuş, ilk müdahale yapılmış ve hasta taburcu edilmiştir. İlerleyen saatlerde ağrı dayanılmaz bir hale gelince halk hekimliği yöntemlerine başvurulma ihtiyacı duyulmuştur. Daha sonra hasta, Mardin ili Kızıltepe ilçesinde yaşayan halk hekimi Ş.B.'ye başvurmuştur. Halk hekiminin eczaneden getirttiği iki ilaç, bal mumu, mum, zeytinyağı ve köy yumurtasından oluşan malzemelerle hazırladığı karışım belirli aralıklarla yaraya uygulanmıştır. Yaklaşık iki buçuk aylık bir tedavi sürecinin ardından yaranın hemen hemen iz bırakmayacak şekilde iyileştĭgi gözlemlenmiştir. Bu uygulamanın en önemli özelliği tedavide geleneksel halk hekimliği ile modern tıbbın olanaklarının birleştirilmesidir. Bu vakada yapılan uygulama, hastalıkların tedavisinde halk hekimliği ve modern tıbbın olanaklarının bir arada kullanılmasının önemini ortaya koymaktadır.

Anahtar Sözcükler: Mardin, Halk Hekimliği, Yanık Tedavisi, Modern Tıp

\section{Burn Applications in Mardin Traditional Folk Medicine}

\begin{abstract}
Folk medicine has emerged with the combination of environmental factors with tradition, tradition, and experience. In Mardin, folk medicine methods and practices continue to exist by changing and developing in parallel with the development of modern medicine. In this study, burn treatment applications, which have an important place in the traditional folk medicine of Mardin, are discussed over a sample burn case. The case subject to this study was monitored from the first day, the applications performed were regularly monitored and recorded. The patient's left hand was burned by pouring hot oil. In the first examination at Mardin State Hospital emergency department, a 2nd-degree burn diagnosis was made, the first intervention was performed and the patient was exited. When the pain became unbearable in the following hours, there was a need to resort to folk
\end{abstract}

Year 4/ 2020, Volume-4, Issue-4 | WWW.ispecjournal.org 
medicine methods. A folk physician living in the district of Kızıltepe in Mardin province applied to Ş.B. The mixture prepared by the folk physician with two medicines, beeswax, wax, olive oil, and village eggs was applied to the wound periodically. It was observed that the wound healed almost without any scar after a treatment period of approximately two and a half months. The most important feature of this practice is the combination of traditional folk medicine and modern medicine in treatment. The application in this case reveals the importance of using the possibilities of folk medicine and modern medicine together in the treatment of diseases.

Key Words: Folk Medicine, Burn Treatment, Mardin, Modern Medicine

\section{Giriş}

İnsanoğlu, çok eski çağlardan beri sağlık problemleriyle karşılaşmış ve bu sorunları ortadan kaldırmak için çeşitli girişimlerde bulunmuştur. Halkın önemli bir kesimi, sağlıkla ilgili problemlerine çözüm bulmak amacıyla sosyoekonomik, iklimsel, ulaşım vb. şartları da göz önünde bulundurarak çeşitli yöntemler geliştirmeye çalışmıştır. Çevresel ve kültürel etmenlerin zaman içinde tecrübeyle birleştirilmesinin bir sonucu olarak halk hekimliğinin ortaya çıktı̆̆ı söylenebilir.

Dünya Sağlık Örgütü (WHO), halk hekimliğini "Bir hastalığı ya da rahatsızlığı teşhis ve tedavi etmek veya hastalığı engellemek için yapılan ruhsal, manuel, bitkisel, madensel uygulamaları da içeren geleneksel tedavi yöntemlerinin tümü." olarak tanımlamaktadır (WHO, 2008). Ünlü Türk folklor araştırmacısı ve yazar Pertev Naili Boratav ise halk hekimliğini, doktora gitmek istemeyen veya gidemeyen kişilerin hastalıklarını tanıma, teşhis etme ve iyileştirme amaciyla başvurduğu yöntem ve uygulamaların tümü, olarak tanımlamaktadır (Boratav, 1994:122). Amerikalı ünlü halkbilimci Don Yoder (1921-2015), halk arasında görülen hastalıkların iyileştirilmesinde uygulanan iyileştirme metotlarının tümü ile hastalıklarla ilgili geleneksel görüşlerin tümünü halk tıbbı olarak tanımlamamıştır (Çifçi, 2019:13). Bu yönüyle Yoder'in halk tıbbının doğal yönüne ek olarak dinsel-büyüsel yönüne de işaret ettiği görülmektedir.

Halk hekimliği dünyanın hemen her bölgesinde varlığını sürdürmekle birlikte, dünya genelinde halk hekimliği yöntem ve uygulamalarının etkin olarak sürdürülmesinde kısmi bir azalma gözlemlenmektedir. Bu ilginin azalmasında modern tıptaki gelişmelerin, halkın sağlık kurumlarına erişiminde ortaya çıkan olanakların, sağlık konusundaki bilinçlenmenin, halkın eğitim ve ekonomik düzeyinin yükselmesinin etkisi olduğu söylenebilir.

Halk tıbbı, folklorik tıp veya halk ilacı olarak da bilinen halk hekimliği, bazen resmi olarak eğitimsiz kitleler tarafından kullanılan bir tedavi yöntemi olarak kabul edilir. Genellikle, gelişmekte olan ülkelerdeki yoksul kitleler halk hekimliğini kullansa da, bazı ülkelerin ulusal sağlık sistemlerine de entegre edildiği görülmektedir. Halk hekimliği, sadece kırsal alanlarda sağlık ihtiyaçlarını karşılamak için değil, gelişmiş ülkelerde de kullanılmaktadır. Yapılan araştırmalar ve gözlemler geleneksel halk hekimliğinin tedavi amaçlı kullanımının devam ettiğini ortaya koymaktadır (Yılmaz, Andsoy, 2020:1).

Year 4/ 2020, Volume-4, Issue-4 | WwW.ispecjournal.org 
Halkın tutum ve davranışları, inanç ve kültürel yaklaşımları, içinde yaşadığı coğrafya ve kültürel ortamın karakterini yansıtır (Sever, 2004:104). Modern tıbbın gelişiminden önce sağlık için tek başvuru yolu olarak kabul gören halk hekimliği uygulamaları, modern tıbbın ulaştığı bilimsel seviye, ilaç sanayisinde gelişmeler ve halkın bunlara erişebilme olanaklarındaki ilerlemelere rağmen halk arasında rağbet görmeye devam etmektedir. Yapılan çalışmalarda, halk hekimliğine olan ilginin sebeplerini ekonomik nedenler, eğitimsizlik, çaresizlik, gelenekçilik, dinî inançların ön plana çıkması, hastanelere ulaşımda çekilen güçlükler, hastanelerde randevu bulmada zorluklar, doktorlardan beklenen ilginin görülmeyişi, bitkisel ilaçların kimyasal ilaçlara tercihi ve geleneksel tıpta olumsuz gelişmenin görülmeyişi olarak sıralamaktadır (Erdoğan, 1997: 215-216).

Halk hekimliği uygulamaları, modern tıptaki gelişmelere, sağlık kurumlarına erişime, halkın bilinç düzeyine, eğitim ve ekonomik düzeyinin yükselmesine bağlı olarak azalmakla beraber varlığını sürdürmeye devam etmektedir. İnsanlar, günlük yaşamında kırık çıkık, incinme, yaralanma gibi birçok sağlık problemiyle karşılaşabilmektedir. Bu sorunlardan biri de yanık vakalarıdır. En kısa tabiriyle yanık; herhangi bir ısıya maruz kalma sonucu oluşan doku bozulmasıdır. Genellikle sıcak su veya buhar teması sonucu meydana gelse de, sicak katı maddelerle temas, asit/alkali gibi kimyasal maddelerle temas, elektrik akımı etkisi ya da radyasyon nedeni ile de oluşabilir. Yanığın ciddiyetini belirleyen faktörler arasında derinlik, yaygınlı, bölge, enfeksiyon riski, yaş, solunum yoluyla görülen zarar ve önceden var olan hastalıklar sayılabilir (http://www.ilkyardim.org.tr/dokumanlar/Saglik-Bakanligi-IlkYardim.pdf Erişim Tarihi: 15.07.2020).

Yanık tedavisi modern tıptaki gelişmelere rağmen bir zorluk olmaya devam etmektedir. Bu nedenle yanıkların tedavisinde halk hekimliği uygulamalarına sıkça başvurulmaktadır. Yanık uygulamaları halk hekimliğinin sadece bir parçasıdır. Halk hekimliğinde yanık uygulamaları, insanoğlunun ateşi bulması ile başlamış ve bugüne kadar devam etmiştir.

$\mathrm{Bu}$ çalışmada, Mardin geleneksel halk hekimliğinde önemli bir yeri olan yanık uygulamalarının örnek bir vaka üzerinden ortaya konulması amacıyla yapılmıştır.

\section{Yöntem}

Bu çalışmada örnek vaka incelemesi yöntemi kullanılmıştır. Bu yöntemde, mevcut durumu göstermek için bir veya iki örnek olay kullanılır. Örnek vaka çalışmaları alışılmadık tanıdık hale getirmek ve okuyuculara söz konusu konu hakkında ortak bir dil vermek öncelikle hizmet vermektedir. Bu çalışmaya konu olan yanık vakası, 16 Mayıs 2020 günü iftar saatinden hemen önce meydana gelmiştir. 31 yaşındaki kadın sağlık çalışanı, yemek hazırlarken yanlışlıkla ocaktaki kızgın yağın dökülmesi sonucu sol elinin parmaklarını ve avuç içini yakmıştır. Olayın hemen ardından özel araçla Mardin Devlet Hastanesi acil servis kliğine başvurulmuştur. Burada yapılan ilk muayenede 2. derece yanık teşhisi konulmuş ve hasta eve gönderilmiştir. Vaka ilk günden itibaren gözlemlenmiş, yapılan tedavi ve 
uygulamalar belirli aralıklarla görsel ve yazılı olarak kayıt altına alınmıştır. Elde edilen veriler tasnif edilmiş ve analiz yapılmıştır.

\section{Vakanın Özeti}

Bu çalışmaya konu olan vaka, 16 Mayıs 2020 günü iftar saatinden hemen önce meydana gelmiştir. 31 yaşındaki kadın sağlık çalışanı, yemek hazırlarken yanlışlıkla ocaktaki kızgın yağın dökülmesi sonucu sol elinin parmaklarını ve avuç içini yakmıştır. Olayın hemen ardından özel araçla Mardin Devlet Hastanesi acil bölümüne başvurulmuştur. Burada yapılan ilk muayenede 2. derece yanık teşhisi konulmuştur. Tedavi olarak bir defaya mahsus olmak üzere bepanthol krem kullanılmış ve hastanın çıkışı yapılmıştır. İlerleyen saatlerde hastanın elinde ve parmaklarında bül denen çok sayıda kabarcık oluşmuştur. Hastanın ağrısı artınca ağrı kesici tablet kullanılmış ancak ağrılarda bir azalma hissedilmemiştir. Hastanın eşi -ki lisans mezunudur- halk hekimliği tedavisini önermiş ve bu amaçla arayış içine girmiştir.

Şekil 1: Yanan el ve parmaklar (16.05.2020)

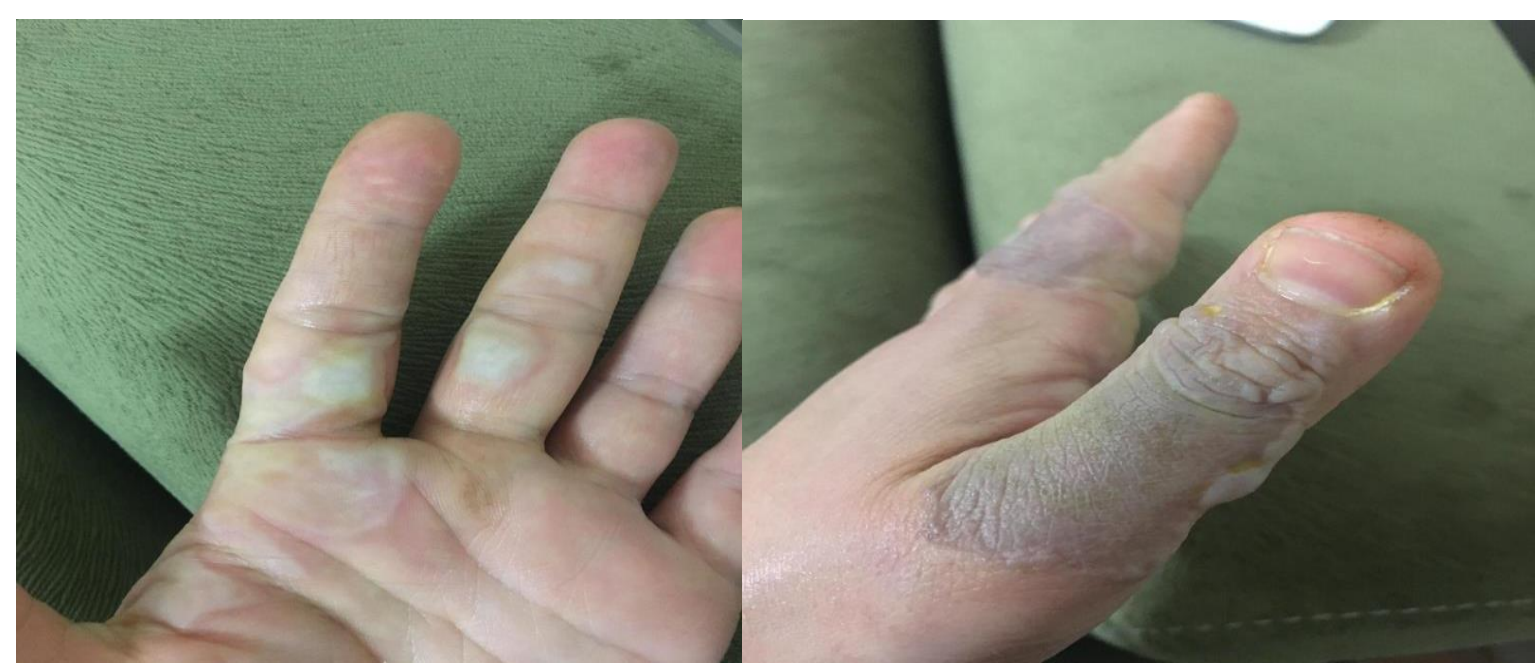

Gece saat 24.00 civarında Mardin Artuklu'da yaşayan 70 yaşındaki halk hekimi S.B'nin torunu olan başka bir sağlık çalışanından temin edilen halk hekimliği mamülü krem biçimindeki karışım yanan bölgeye uygulanmıştır. Hasta ilk 15 dakika ciddi bir ağrı hissetmiş akabinde ağrıları tamamen dinmiştir. Takip eden günlerde yanığın tedavisi amacıyla herhangi bir sağlık kuruluşuna başvurmamıştır.

Karışımın olumlu etkisini gören hasta ve hasta yakını, ertesi gün Mardin ili Kızıltepe ilçesinde yaşayan 64 yaşındaki halk hekimi Ş.B’ye başvurmuştur. Halk hekimi, okuma yazma bilmediğini ve bu karışımın hazırlanış şeklini büyüklerinden öğrendiğini beyan etmiştir. Halk hekimi Ş.B, karışımı hazırlamak üzere, hasta yakınından aşağıdaki malzemeleri temin etmesini istemiştir. 


\section{Karışım için kullanılacak malzemeler:}

2 adet RİF ampul (eczaneden temin edilmek üzere)

2 adet toz antibiyotik (saşe biçiminde ve eczaneden temin edilmek üzere)

2 adet beyaz mum,

250 gr balmumu,

300 gr kristal zeytinyağı,

2 adet köy yumurtası

\section{Karışımın hazırlanması:}

Beyaz mumlar ve bal mumu bir tavaya konulup 300 gr zeytinyağı il beraber 5 dakika boyunca karıştırılarak eriyinceye kadar 1sıtılır. Daha sonra katılaşmak üzere soğumaya bırakılır. Soğuyan karışımın üzerine iki adet köy yumurtasının sadece sarısı, iki adet toz şeklindeki antibiyotik ve iki RİF ampul ilave edilerek merhem haline gelinceye kadar karıştırılır.

Elde edilen karışım kapalı bir plastik kaba konulur. Karışım uygulanmadan önce yanan bölge 1lık su ve sabun ile yıkanır. Karışım ilk 15 gün boyunca sabah ve akşam olmak üzere günde iki defa kanatlı hayvan tüyü yardımıyla uygulanır. 16. günden itibaren yara iyileşinceye kadar günde bir kez uygulanmaya devam edilir. Karışım, buzdolabında ve ağzı kapalı tutulmak suretiyle saklanabilmektedir.

Şekil 2: Yanık tedavisi için hazırlanan karışım

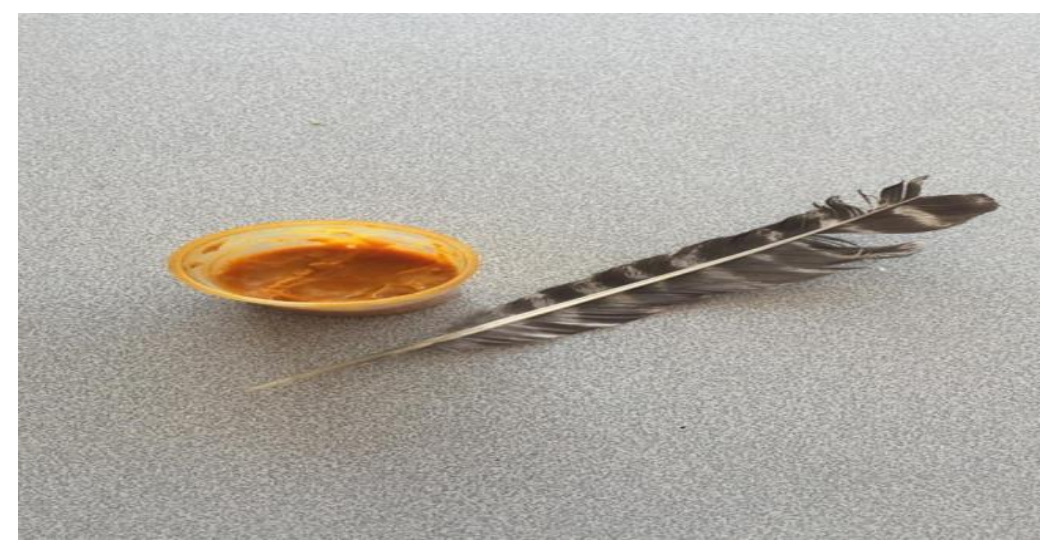

Karışım turuncu bir görünümde olup merhem şeklindedir. Yaranın hassasiyeti göz önünde bulundurularak uygulamada kanatlı hayvan tüyünden yararlanılmaktadır. 


\section{Yanık yarasının iyileşme sürecine ait şekiller}

Şekil 3: Üç gün sonra yanan el ve parmaklar

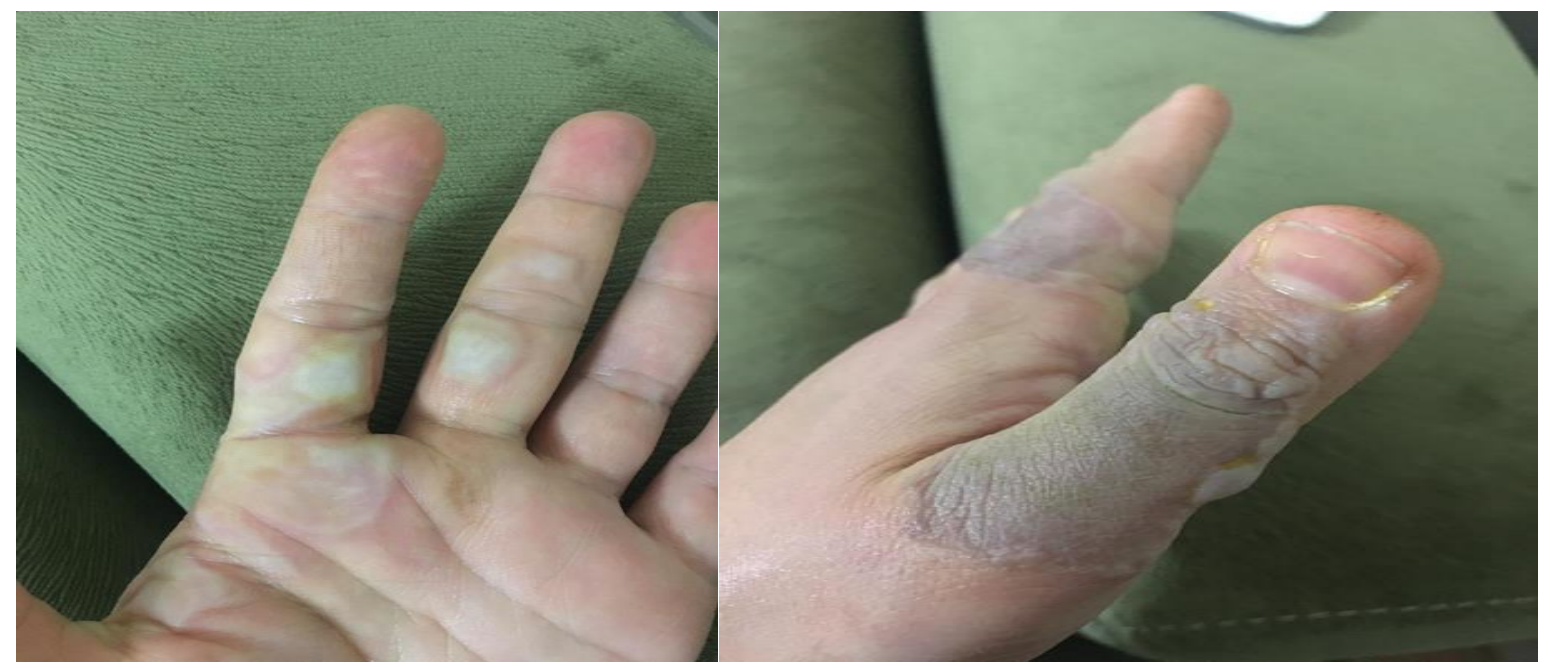

Halk hekimliği tedavisinin üçüncü gününde yanan bölgedeki morarmanın azalmaya başladığı, parmaklarda ve avuç içinde meydana kabarcıkların inceldiği gözlemlenmiştir. Hasta herhangi bir ağrı hissetmediğini beyan etmiştir. Her uygulamadan önce yanan bölge 1lık su ve sabunla yıkanmaktadır. Uygulama boyunca yanan bölge açık bırakılmaktadır.

Şekil 4: Yedi gün sonra yanan el ve parmaklar

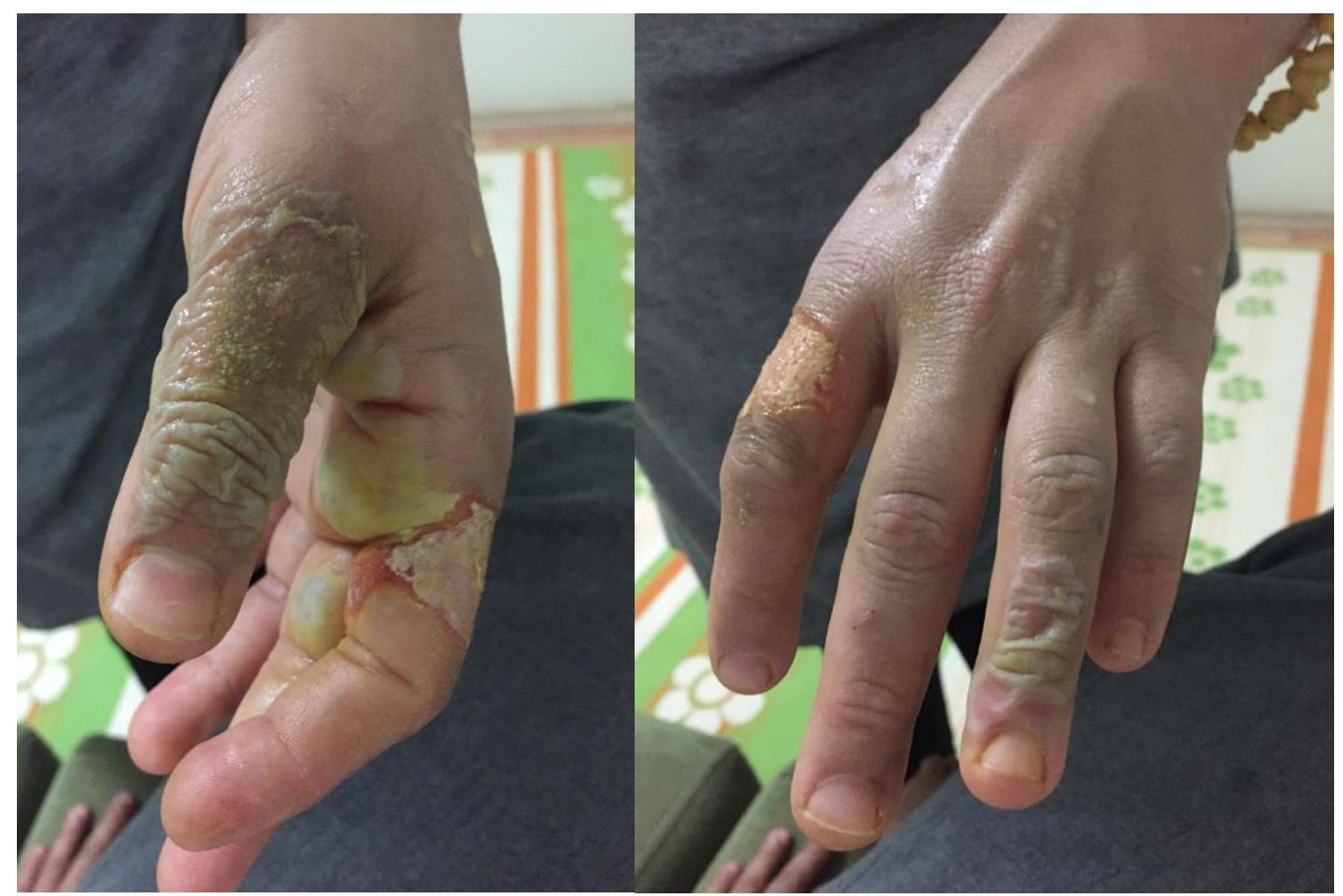

Year 4/ 2020, Volume-4, Issue-4 | WWW.ispecjournal.org 
Olaydan bir hafta sonra derideki kabarcıkların söndüğü görülmektedir.

Şekil 5: On gün sonra el ve parmaklar

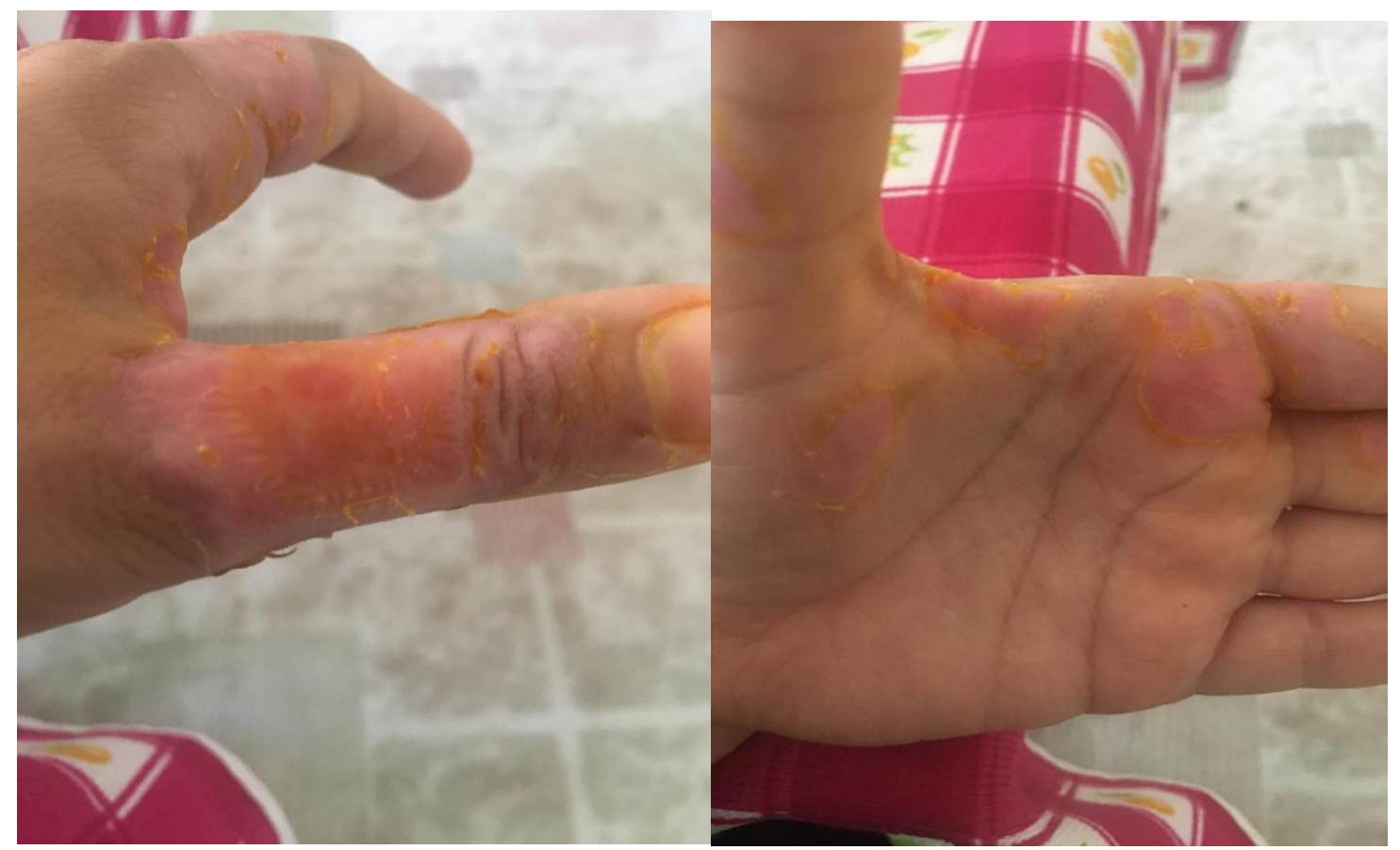

Vakanın ortaya çıkmasından on gün sonra hasar gören dokunun soyulduğu ve yeni bir deri tabakasının geliştiği gözlemlenmektedir.

Şekil 6: On beş gün sonra parmaklar ve avuç içi

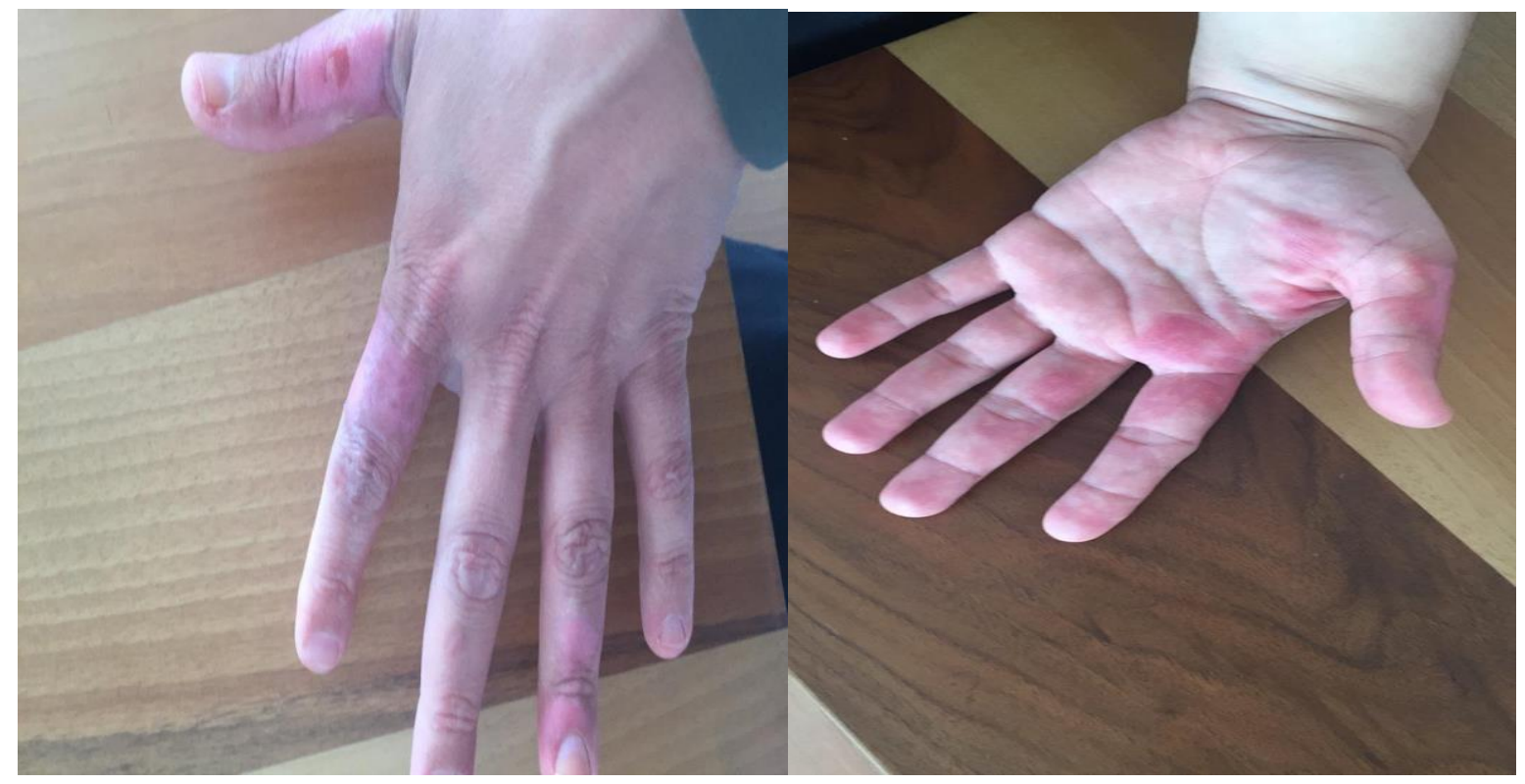

Uygulamadan on beş gün sonra hasar gören dokunun temizlendiği, derinin kırmızı bir hal aldığı görülmektedir. Doku kendisini yeniden onarma aşamasına geçmiştir. 
Şekil 7: Yirmi dört gün sonra parmaklar

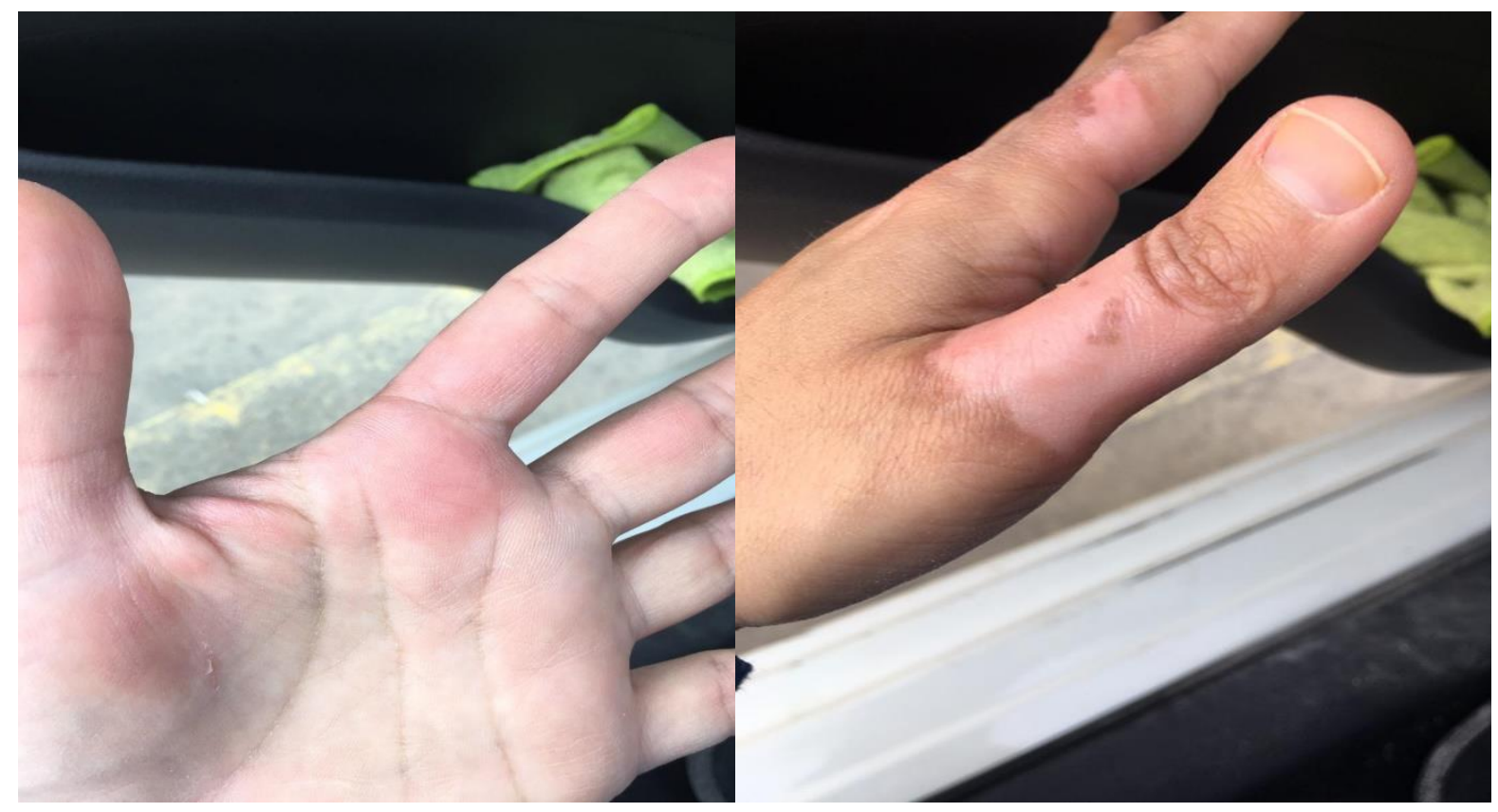

Olaydan 24 gün sonra doku doğal görünümüne yakın bir hal almıştır.

Şekil 8: Otuz yedi gün sonra el ve parmaklar

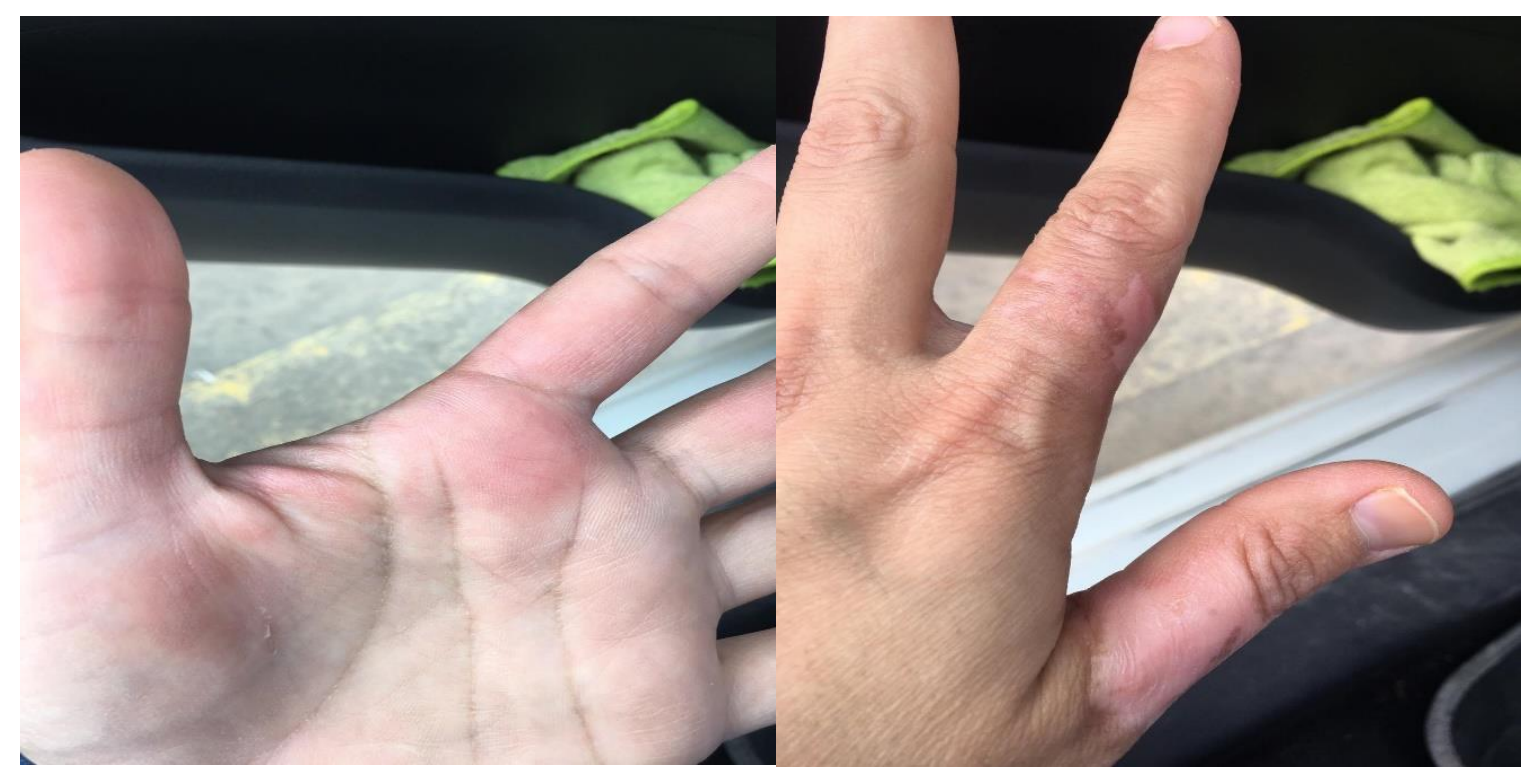

Hasta, kamuda çalışan sağlık personeli olduğu için Kovid-19 pandemisinden etkilenen hastalara yardım etmek üzere 15. günden itibaren iş hayatına geri dönmüştür. Gün içinde cerrahi eldiven kullanmaya bağlı olarak cilt havasız kalmış, karışımın yanık üzerinde kalma süresi sınırlanmıştır. $\mathrm{Bu}$ durum, yanık tedavisinde aksamalara yol açmıştır. $\mathrm{Bu}$ nedenle iyileşmede yavaşlama gözlemlenmiştir. Buna rağmen, yukarıdaki şekilde de görüldüğü gibi yanığın dokuya verdiği hasar neredeyse ortadan kalkmıştır. Hastanın el ve parmak hareketlerinde herhangi bir kısıtlanma gözlemlenmemiştir.

Year 4/ 2020, Volume-4, Issue-4 | WwW.ispecjournal.org 


\section{Tartışma}

Hastalıklardan korunma veya hastalıkların iyileştirilmesinde, yaşanan olaylardan elde edilen bilgi ve tecrübelerin dinsel-büyüsel yorumlardan da destek alarak nesilden nesile aktarılması sonucu halk hekimliği ortaya çıkmış ve varlığını sürdüregelmiştir (Şar, 2005: 131). Dünyanın hemen her yerinde yanık tedavisi ile ilgili halk hekimliği uygulamalarına rastlamak mümkündür. Bu uygulamalar halkın bilgi, tecrübe, inanç ve kültürel birikimine bağlı olarak farklılık gösterebilmektedir. İran'da, yanığın geleneksel tedavisinde yeşil çay, dağ çayı ve papatya; Güney Afrika'da çeşitli bitkilerin yaprakları; Kenya'da haşlanmış patates, bitki yapraklarının külü; Mali'de susam gibi bazı tohumların yağları, kullanılmaktadır. Antik Roma ve Mısır'da yanıkların tedavisinde yağ, balmumu ve gül suyu kullanılıyordu (Albertyn, Berg, Numanoglu, Rode, 2015: 203-211).

Türkiye'nin hemen her bölgesinde yanık ile ilgili halk hekimliği uygulamalarına rastlamakla birlikte uygulamalar arasında farklı uygulamalara rastlamak mümkündür.

Şanlıurfa'da yanığın şiddetine göre farklı uygulamalara başvurulmaktadır: Beyaz mum ve yumurta sarısı karıştııılıp merhem kıvamına getirildikten sonra yanan bölgeye uygulanır; daha yara tazeyken patates dilimlenir ve yanık olan kısma konur. İki üç adet yumurta sarısı tavada kızartıp yumurtadaki yağ yüzeye çıktıktan sonra yanık bölgeye sürülür. Domates salçası ve zeytinyağı bölgeye uygulanır. İki-üç gün aynı işlem devam eder. Yanık olan kısım deriyi değiştirecektir. Sirke suyu ile yara temizlenir. Yumurta sarısı ya da sadece akı sürülür ve yanık kısmındaki iltihabın dışa akıtılması sağlanır. 10-15 dakika bekletilir. İltihap aktıktan sonra soğuk su ile yıkanıp bağlanır. Domates dilimlenir ve yaranın üstüne konur (Köprüdüz, 2019: 72). Adıyaman'da ileri derecedeki yanıklarda yumurta sarısı ve zeytinyağından yararlanılır. Yumurtanın sarısı, yanıncaya kadar kavrulur. Daha sonra biraz zeytinyağı ilave edilerek em hazırlanır. Kanatlı hayvan tüyleri yardımıyla merhem biçiminde yanan bölgeye sürülür. Bu uygulama yanığın açtığı yaralar iyileşinceye kadar günde iki defa tekrarlanır. her uygulamadan önce yanık olan bölge 1lık su ve sabunla yıkanır (Çifçi, 2019: 201). Hatay halk hekimliğinde, öncelikle yanık olan bölge soğuk su ile yıkanır. Daha sonra calba denilen bir bitkinin yaprakları havanda dövülerek merhem haline getirilir ve yanık olan bölgeye sürülür. $\mathrm{Bu}$ işlem bir süre için her gün tekrarlanır (Arı, Top; 2017: 61). Mersin'de pılnar denilen bitkinin kökü kaynatılarak yanık bölgeye sürülür (Sever, 2001:162). Sinop'ta yanığın derecesine göre, kireç zeytinyağı ile karıştırılarak yanığın üstüne sürülür; tavuk kemiği yakılır ve külü sürülür; salça, tuz veya zeytinyağı sürülür (https://sinop.ktb.gov.tr/TR-74864/halkhekimligi.html Erişim Tarihi 28.07.2020). Antalya'da, Adıyaman'daki uygulamaya benzer olarak, birkaç yumurta kırılarak üzerine yağ ilave edilmeden yumurtanın kendi yağı çıkana kadar pişirilir. Yüzeye çıkan yağ, soğutulduktan sonra yanık bölgeye sürülür (Gönenç, 2011: 55). Anadolu'nun bazı bölgelerinde yanık tedavisinde yumurta yağına ek olarak elma suyundan da yararlanılmaktadır (Özyurt, 2018: 53).

Çalışmamıza konu olan örnek vaka incelenmesinde kullanılan geleneksel tedavi yöntemi, tedavide kullanılan malzemeler açısından benzerlikler taşımakla beraber temelde Türkiye'nin diğer bölgelerinde yapılan uygulamalardan farklıdır. 


\section{Sonuç}

Sağlık söz konusu olduğunda insanoğlunun olağanüstü bir çabanın içine girdiği görülmektedir. $\mathrm{Bu}$ mücadele alanlarından biri de yanık tedavisidir. Yanık tedavisinde, binlerce yıllık geçmişe dayanan tecrübelerden yola çıkarak deneme yanılma başta olmak üzere çeşitli yöntemlere başvurulmaktadır. Modern tıbbın gelişimine ve sağlık kurumlarına erişim olanaklarına bağlı olarak halk hekimliği uygulamalarında nispi bir gerileme görülmektedir. Bununla beraber halk hekimliği varlığını sürdürmektedir. Halk hekimliği ile modern tıbbın kesiştiği alanlardan biri Mardin halk hekimliğinde rastlanan yanık tedavisidir. Çalışmada ele alınan vaka, Mardin'de yanık tedavisinde halk hekimliği uygulamalarının devam ettiğini göstermektedir.

Halk hekimliği uygulamasına başvuran kişinin sağlık personeli olması, önce hastaneye daha sonra halk hekimine başvurması, halk hekimlerinin halk eğitimli kesimi dahil bütün kesimlerde güvenilir bir yöntem olarak ilgi görmeye devam ettiğine işaret etmektedir.

Karışımın hazırlanmasında eczaneden temin edilen ilaçlardan da yararlanılması, halk hekimliğinin modern tıpla ilişkilendirilmesi bakımından önemlidir.

Laboratuvar ve deneysel çalışmalarla bilimsel olarak desteklenmesi durumunda sağlık problemleri ile etkili bir şekilde mücadele edilmesinde halk hekimliği uygulamalarından yararlanılabileceğini ortaya koymuştur.

Sahada yapılacak benzer çalışmalar, geleneksel tıp, koruyucu hekimlik veya tamamlayıcı tıp olarak literatüre ve tedavi prosedürlerine dâhil edilebilir. Ayrıca, bu tür çalışmalar modern tıbbın yanında birer yardımcı ve destekleyicidir.

$\mathrm{Bu}$ çalışma, Mardin halk hekimliğinin bütün yönleriyle araştırılması, derlenmesi ve tasnif edilmesi kayıt altına alınması bakımından önemlidir.

\section{Kaynaklar}

Albertyn, R., Berg, A., Numanoglu, A., Rode, H. (2015). Traditional burn care in sub-Saharan Africa: a long history with wide acceptance. Burns : journal of the International Society for Burn Injuries, 41(2), 203-211. https://doi.org/10.1016/j.burns.2014.06.005

Arı, B, TOP, MB. (2017). Hatay'da Sağlık Sorunlarını Gidermek İçin Başvurulan Başlıca Halk Hekimliği Uygulamaları. Karadeniz Uluslararası Bilimsel Dergi, 33(33), 55-67.

Boratav, PN, 100 Soruda Türk Folkloru. Gerçek Yayınevi, İstanbul 1994.

Çifçi, T. (2019). Adıyaman ve Çevresinde Halk İnançları ve Halk Hekimliği (Baweriyên Gelêrî û Dermanê Kurmancî li Herêma Semsûrê), Doktora Tezi, Dicle Üniversitesi Sosyal Bilimler Enstitüsü Kürt Dili ve Kültürü Anabilim Dalı: Diyarbakır. 
Erdoğan Z, (1997). Ankara'nın Kazan ve Kalecik İlçelerinde ve Bunlara Bağlı Köylerde Halk Hekimliği, V. Milletlerarası Türk Halk Kültürü Kongresi-Gelenek, Görenek ve İnançlar, Ankara: Kültür Bakanlığı Yayınları.

Gönenç, A.(2011), Antalya İli Korkuteli İlçesinde Halk İnançları ve Halk Hekimliği, Yüksek Lisans Tezi, Selçuk Üniversitesi SBE Türk Dili ve Edebiyatı Ana Bilim Dalı Türk Halk Edebiyatı Bilim Dalı, Konya.

Köprüdüz, İH. (2019). Siverek Halk Hekimliği Uygulamaları, Çă̆ Üniversitesi Sosyal Bilimler Enstitüsü Türk Dili ve Edebiyatı Anabilim Dalı, Yüksek Lisans Tezi, Mersin.

Özyurt, B. (2018), Anadolu'da Uygulanan Halk Tedavilerinden Bazı Örnekler. Gaziosmanpaşa Üniversitesi Tıp Fakültesi Dergisi, 10(4), 151-156.

Sever, M. (2001). Mersin ve Yakın Çevresi Halk İnançları ve Halk Hekimliği, (Yayınlanmamış Doktora Tezi), Hacettepe Üniversitesi SBE, Ankara.

Sever, M. (2004). Türk Halk İnançlarında ve Halk Hekimliği Uygulamalarında Meyve. Türklük Bilimi Araştırmaları, (16).

Sinop Halk Hekimliği, https://sinop.ktb.gov.tr/TR-74864/halk-hekimligi.html Erişim Tarihi 28.07.2020.

Şar, S. (2005). Anadolu Halk Hekimliği Uygulamalarına Genel Bir Bakış, Türkiye Klinikleri Tip Etiği-Hukuku-Tarihi Dergisi, 13:131-136.

World Healt Organization. (2008). Traditional Medicine www.who.int/mediacentre/factsheets/fs134/en (17.05.2018)

Y1lmaz, E., Andsoy, I. I. (2020). Traditional and modern practices in wounds and burn injuries in a population of North Western Turkey. Burns : journal of the International Society for Burn Injuries, S0305-4179(19)30838-1. 